\title{
The Effect of Corporate Philanthropy on Organization Commitment and Job Performance of Employees: Workplace Spirituality as Mediating Variable
}

\author{
Jiang-Lin Ke, Xiao-Wei Qiu*, Yi-Fan Jiang \\ School of Government, Beijing Normal University, Beijing, China \\ Email: kejianglin@126.com,
}

Received 8 June 2015; accepted 26 June 2015; published 29 June 2015

Copyright (C) 2015 by authors and Scientific Research Publishing Inc.

This work is licensed under the Creative Commons Attribution International License (CC BY). http://creativecommons.org/licenses/by/4.0/

\section{(c) (i) Open Access}

\begin{abstract}
The article is aimed at examining the effect of corporate philanthropy on employees' organization commitment and job performance through the angle of workplace spirituality. For this purpose, the data were collected from 347 employees working in different corporations in Beijing. By regression analysis, we found that corporate philanthropy had a positive effect on organization commitment and job performance, meanwhile workplace spirituality played a partly mediating role. All the alternate hypotheses of the study were accepted. According to these research results, it is suggested that corporations should engage in philanthropy activities and take some other measures for promoting employees' workplace spirituality.
\end{abstract}

\section{Keywords}

Corporate Philanthropy, Organization Commitment, Job Performance, Workplace Spirituality

\section{Introduction}

How to enhance employee's commitment and job performance is an important issue for human resource management. Organizational commitment has been operationally defined by Bateman and Strasser as "multidimensional in nature, involving an employee's loyalty to the organization, willingness to exert effort on behalf of the organization, degree of goal and value congruency with the organization, and desire to maintain membership" [1]. This construct consists of three dimensions, which are emotional, sustained, and normative commitment [2]. "Corresponding author.

How to cite this paper: Ke, J.-L., Qiu, X.-W. and Jiang, Y.-F. (2015) The Effect of Corporate Philanthropy on Organization Commitment and Job Performance of Employees: Workplace Spirituality as Mediating Variable. American Journal of Industrial and Business Management, 5, 466-473. http://dx.doi.org/10.4236/ajibm.2015.56046 
Some studies have shown that organization commitment can be influenced by many factors such as leadership styles, organizational support, organization reliability, fairness and collective work ethic [3]. Job performance is typically conceptualized as "actions and behaviors that are under the control of the individual that contribute to the goals of the organization" [4]. As for the organizational values of corporate philanthropy, it has been researched by some scholars. Especially with the emergence of strategic philanthropy theory [5], more and more companies began to improve their business environment through corporate philanthropy [6]. It has been illustrated that the corporate philanthropy has a positive effect on accumulating reputation capital [7], improving financial performance [8], and attracting more excellent employees [9]. Meanwhile, a few scholars begin to focus on the effect of corporate philanthropy on employees' work attitude and performance [10]. Xu found that $67.1 \%$ of managers acknowledged that corporate philanthropy enhanced employees' organization cohesion and loyalty in his survey. Balakrishnan believed that corporate philanthropy would have a significant altruistic impact on employees, such as a significant increase on employee contribution, incentive, and dedication [11]. These factors work together to help achieve an overall higher level of work efficiency.Through a case study, Ke et al. [12] claimed that the work attitude and behavior of employees in a philanthropically positive corporate were better than those in a philanthropy-negative corporate. However, right now the relevant empirical researches, especially large-scale sample test in this area, are still deficient.

With the rise of the spiritual theory, more and more organizations have begun to focus on the spiritual needs of their employees. Workplace spirituality is the affirmation of employee's inner life of the employees. Workplace spirituality can be defined as the "recognition that employees have an inner life which nourishes and is nourished by meaningful work taking place in the context of a community" [13], including three dimensions which are meaningful at work, community and alignment with organizational values [14]. Research has shown that workplace spirituality plays an important role on job involvement [15], job satisfaction, organizational commitment [16] and job performance [17]. By creating a caring organizational atmosphere, corporate philanthropy provides a spiritual experience to employees, which enables employees to better understand the value and significance of their work, align their goals with organizational goals and effectively improve the spirituality of employees at workplace; at the same time, based on Social Exchange Theory, after feeling the concern from the organization, employees can have a high level of workplace spirituality, and they will return the favor to the organization by improving their organizational commitment and job performance. In a case study, Ke, Sun and Qiu have illustrated that the corporate philanthropy positively affects employees' attitude and behavior, such as job involvement and organization commitment, and have proposed that the workplace spirituality may be a mediator [12].

However, the current research on organizational values of corporate philanthropy is still in the infancy stage; especially the influence process of corporate philanthropy on employees' attitudes and work outcomes needs to be analyzed and tested. Therefore, this study explores the effect of corporate philanthropy on organization commitment and job performance through the angle of workplace spirituality.

\section{Literature and Hypothesis}

Corporate philanthropy is a voluntary altruistic behavior which doesn't request obligatory repayment. This includes both external philanthropy and internal philanthropy [10]. External philanthropy refers to philanthropic actions taken by the corporate which are then received by a third party, whilst internal corporate philanthropy means philanthropic actions made by the corporate and received by its own employees. On one hand, corporate philanthropy can enhance the reputation capital, so it will have a positive impact on the emotional commitment for the employees [18]. On the other hand, the internal corporate philanthropy can directly benefit the internal employees, and provide not only a caring and positive atmosphere, but also an valuable spiritual experience for the employees. The positive behavior of the corporate could advocate altruistic behaviors, promote employees' incentive and motivation to work harder and perform better [11]. Besides, based on Social Exchange Theory, the relationship between organization and employees follows a principle of reciprocity, and employees serve organization in order to obtain economic or social remuneration. When individuals receive economic and social emotional resources that are offered by organization, they tend to feel certain obligation to give back to the organization [19]. Therefore, corporate philanthropy will strengthen the employees' organizational recognition and commitment, improve their working performance. This leads to the following hypothesis:

H1a Corporate philanthropy can promote employee's organization commitment.

$H 1 b$ Corporate philanthropy can promote employee's job performance. 
When Riasudeen and Prabavathy studied the relationship between workplace spirituality of the employees in manufacturing and the five kinds of work attitude, they found that workplace spirituality affects job satisfaction and organization commitment positively, which can bring higher productivity and responsibility for employees [15]. Consequently, the overall mood and proactivity of employees will experience an elevation [20]. Meanwhile, employees that already deliver high levels of job involvement will perform even more enthusiastically to achieve organizational goals, improve their organization commitment and job performance [21]. Concurrently, Rastgar surveyed 300 Iranian insurance company employees and found that workplace spirituality is significantly interrelated to the work performance [17]. This research also suggested that employees who have high workplace spirituality will show more organizational citizenship behaviors. For this reason, their job performance will be improved. This leads to the following hypothesis:

H2a Workplace spirituality can promote employee's organization commitment.

$H 2 b$ Workplace spirituality can promote employee's job performance.

Researchers have found that workplace spirituality is affected by various factors, such as leadership style, organization atmosphere and so on [22]. Based on the Theory of Identity, individuals in a philanthropic organization will realize the essence of emotion and value inspired from participating as a member of a specific group after the realization of their own affiliations to belong to a social community [23]. Philanthropic corporate behavior will establish a exceptionally responsible corporate image, create a nurturing and benevolent organizational atmosphere, implement a positive psychological experience for employees and then reinforce their affirmation for the corporate. Therefore the understanding of the intrinsic value of work via a series of measures, which includes active care of well-being of, fulfillment of familial responsibilities, and creation of a supportive work environment for employees, and aid to social vulnerable groups and so on. Meanwhile, Ke, Sun and Qiu have illustrated the corporate philanthropy positively affect employees' attitude and behavior, such as job involvement, organization commitment, and propose the workplace spirituality may be a mediator in a case-study [12]. This leads to the following hypothesis:

H3a. Workplace spirituality mediates the relationships between the corporate philanthropy and organization commitment.

H3b. Workplace spirituality mediates the relationships between the corporate philanthropy and job performance.

The study model is shown in Figure 1.

\section{Method}

\subsection{Sample}

The article uses self-report questionnaire for convenient sampling. The sample for the study was drawn from corporate employees in Beijing. All the participants prior to data collection were informed consent signed. Out of the total 420 questionnaires distributed, 380 copies were returned and 347 of them were valid. The effective response rate is $82.6 \%$. Invalid samples included those who didn't fill all the questions or fill the questions casually. The descriptive statistics of samples are shown in Table 1.

\subsection{Measuring}

Corporate philanthropy. The paper uses the scale of corporate philanthropy developed by Ke et al. [10] This scale includes both an internal and external dimension, with a total of 19 items with 6 point Likert-style scale

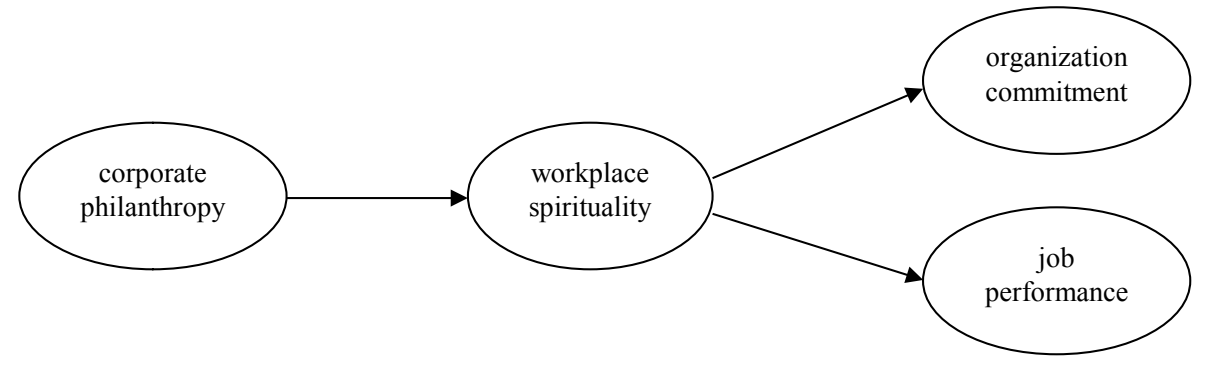

Figure 1. The effect of corporate philanthropy on organization commitment and job performance of employees. 
Table 1. Descriptive statistics of samples.

\begin{tabular}{ccc}
\hline Gender & Male & $48.8 \%$ \\
Marriage & Female & $51.2 \%$ \\
Work experience & Married & $62.8 \%$ \\
& Unmarried & $37.2 \%$ \\
Educational background & $1-5$ years & $53 \%$ \\
& $6-10$ years & $19 \%$ \\
& $11-15$ years & $4.6 \%$ \\
& $>15$ years & $23.3 \%$ \\
High school and under & $2 \%$ \\
\hline
\end{tabular}

$(1=$ fully disagree, $2=$ disagree, $3=$ a little disagree, $4=$ a little agree, $5=$ agree, $6=$ fully agree $)$. The overall alpha was 0.87 .

Workplace spirituality. This includes 21 items from Milliman et al. [14] spirituality scale. The scale contains three dimensions which include meaningful at work, community and alignment with organizational values. The measures were based on a six-point scale from 1 ("completely disagree") to 6 ("completely agree") and the overall alpha was 0.93 .

Organization commitment. This includes 18 items from Meyer and Allen's [2] organization commitment scale, including three dimensions, affective, continuance, and normative commitment. The measures were based on a six-point scale from 1 ("completely disagree") to 6 ("completely agree") and the overall alpha was 0.81 .

Job performance. The paper uses the scale compiled by Williams \& Anderson [24]. It includes a total of 22 items, including two dimensions of task performance and contextual performance. The measures were based on a six-point scale from 1 ("completely disagree") to 6 ("completely agree"). The overall alpha was 0.81 .

Control variables. Control variables includes gender, marriage, work experience and educational background. Specifically, gender: $0=$ male, $1=$ female; marriage: $0=$ yes $1=$ no; working experience: $1=$ " $1-5$ years", $2=$ " 6 - 10 years", $3=$ " $11-15$ years", $4=$ ">15 years"; educational background: 1 = high school and under", $2=$ "secondary vocational school", 3 = "bachelor", 4 = "master", 5 = "doctor".

\subsection{Common Method Biases Test}

In order to reduce the common method bias, the questionnaire instructions says that it is an anonymous survey and there are no right or wrong answers, and ensure that the result does not reveal any personal information. The purpose is to enable participants to complete the questionnaire with honesty and not to be influenced by questions before and after. In addition, we use the Harman single factor test to verify the extent of homologous error of each research variable. The results show that the single factor can only explain $15.47 \%$ of the four subjective variables' variance, indicating common method biases are not serious.

\subsection{Methods of Data Analysis}

After data collation, correlation coefficient and regression analyzing of variables was used by SPSS 19.0 for the study to explore the relationship among corporate philanthropy, workplace spirituality, organization commitment and job performance. 


\section{Results}

\subsection{Correlation Analysis of Variables}

Table 2 shows the mean and correlation coefficient of variables. The mean and standard deviation don't have any abnormal phenomena. The results show that corporate philanthropy has a significant role in promoting organization commitment $(\mathrm{r}=0.360, P<0.001)$ and a significant role in promoting job performance $(\mathrm{r}=0.106, P$ $<0.05$ ). These results support H1a and H1b. Meanwhile, corporate philanthropy also has a significant positive effect on organization commitment $(\mathrm{r}=0.268, P<0.001)$ and a significant positive effect on job performance $(\mathrm{r}$ $=0.138, P<0.01)$. These results support $\mathrm{H} 2 \mathrm{a}$ and $\mathrm{H} 2 \mathrm{~b}$.

\subsection{The Effect of Corporate Philanthropy and Workplace Spirituality on Organization Commitment}

Model 1 - 3 in Table 3 shows the influence of corporate philanthropy and workplace spirituality on organization commitment. The VIF of model $1-3$ is less than the critical value of 10 . The $\mathrm{D}-\mathrm{W}$ value is significant at the 0.05 level which shows that the model does not have the serious problem of collinearity, and the analysis of the

Table 2. Means, standard deviation, Pearson correlation coefficient of variables.

\begin{tabular}{lccccccccc}
\hline & Mean & SD & $\mathbf{1}$ & $\mathbf{2}$ & $\mathbf{3}$ & $\mathbf{4}$ & $\mathbf{5}$ & $\mathbf{6}$ & $\mathbf{7}$ \\
\hline 1. Gender & 0.48 & 0.500 & & & & & & & \\
2. Marriage & 0.42 & 0.580 & $\mathbf{0 . 0 7 8}$ & & & & & & \\
3. Work experience & 1.98 & 1.231 & $0.383^{* *}$ & $-0.195^{* *}$ & & & & & \\
4. Educational Background & 3.49 & 0.817 & $0.113^{*}$ & $0.113^{*}$ & -0.044 & & & & \\
5. Corporate philanthropy & 3.895 & 0.932 & $0.168^{* *}$ & $0.168^{* *}$ & $-0.231^{* *}$ & $0.145^{* *}$ & & & \\
6. Workplace spirituality & 3.376 & 0.922 & $-0.26^{* *}$ & $-0.164^{* *}$ & -0.098 & -0.074 & $0.200^{* * *}$ & & \\
7. Organization commitment & 3.509 & 1.200 & 0.050 & $0.225^{* *}$ & -0.024 & $0.276^{* *}$ & $0.360^{* * *}$ & $0.268^{* * *}$ & \\
8. Job performance & 4.211 & 0.961 & $0.408^{* *}$ & 0.021 & $0.463^{* *}$ & $0.277^{* *}$ & $0.106^{*}$ & $0.138^{* * *}$ & $0.449^{* * *}$
\end{tabular}

Notes: ${ }^{* * *} P=0.001 ;{ }^{* *} P=0.01 ;{ }^{*} P=0.05$.

Table 3. Regression analyzing of corporate philanthropy and workplace spirituality on organization commitment and job performance.

\begin{tabular}{|c|c|c|c|c|c|c|}
\hline & \multicolumn{2}{|c|}{ Organization commitment } & \multicolumn{2}{|c|}{ Job performance } & \multirow[b]{2}{*}{ Model 5} & \multirow[b]{2}{*}{ Model 6} \\
\hline & Model 1 & Model 2 & Model 3 & Model 4 & & \\
\hline \multicolumn{7}{|l|}{ Control variable } \\
\hline Gender & -0.013 & -0.001 & 0.076 & $0.214^{* * *}$ & $0.220^{* * *}$ & $0.277^{* * *}$ \\
\hline Marriage & $0.204^{* * *}$ & $0.165^{* *}$ & $0.209^{* *}$ & 0.053 & 0.031 & 0.064 \\
\hline Work experience & 0.032 & 0.093 & 0.057 & $0.403^{* * *}$ & $0.438^{* * *}$ & $0.412^{* * *}$ \\
\hline Educational background & $0.256^{* * *}$ & $0.215^{* * *}$ & $0.230^{* * *}$ & $0.260^{* * *}$ & $0.236^{* * *}$ & $0.247^{* * *}$ \\
\hline \multicolumn{7}{|l|}{ Independent variable } \\
\hline Corporate philanthropy & & $0.323^{* * *}$ & $0.253^{* *}$ & & $0.186^{* * *}$ & $0.134^{* *}$ \\
\hline \multicolumn{7}{|l|}{ Mediating variable } \\
\hline Workplace spirituality & & & $0.288^{* * *}$ & & & $0.212^{* * *}$ \\
\hline $\mathrm{R}^{2}$ & 0.115 & 0.211 & 0.282 & 0.347 & 0.379 & 0.417 \\
\hline Adjusted $\mathrm{R}^{2}$ & 0.105 & 0.199 & 0.269 & 0.339 & 0.369 & 0.407 \\
\hline $\mathrm{F}$ & 11.148 & 41.198 & 33.575 & 45.442 & 17.275 & 22.349 \\
\hline$\Delta \mathrm{R}^{2}$ & 0.115 & 0.095 & 0.071 & 0.347 & 0.031 & 0.038 \\
\hline $\mathrm{F}$ & 11.148 & 18.206 & 22.217 & 45.442 & 41.539 & 40.507 \\
\hline
\end{tabular}

Notes: ${ }^{* * *} P=0.001 ;{ }^{* *} P=0.01 ;{ }^{*} P=0.05$. 
model is acceptable. According to model 1, gender and work experience do not have significant effect on organizational commitment and education background have influence on organization commitment in some degree. Model 2 shows that the $\beta$ of corporate philanthropy is $0.323(P<0.001)$. Corporate philanthropy has significant positive effect on organization commitment of subordinates. Model 3 shows that after introducing the variable of workplace spirituality, the $\beta$ of workplace spirituality is $0.288(P<0.001)$, while the $\beta$ of corporate philanthropy is 0.253 which is lower than before. It shows that workplace spirituality plays a partly mediating role between corporate philanthropy and organization commitment. These results support H3a.

\subsection{The Effect of Corporate Philanthropy and Workplace Spirituality on Job Performance}

Model 4 - 6 in Table 3 shows the influence of corporate philanthropy and workplace spirituality on job performance. The VIF of model $1-3$ is less than the critical value of 10 . The D-W value is significant at the 0.05 level which shows that the model does not have the serious problem of collinearity, and the analysis of the model is acceptable. According to model 4, gender, education background and work experience have positive influence on job performance. Model 5 shows that the $\beta$ of corporate philanthropy is $0.186(P<0.001)$. Corporate philanthropy has significant positive effect on job performance of employees. Model 6 shows that after introducing the variable of workplace spirituality, the $\beta$ of workplace spirituality is $0.212(P<0.001)$, while the $\beta$ of corporate philanthropy is $0.134(P<0.01)$ which is lower than before. It shows that workplace spirituality plays a partly mediating role between corporate philanthropy and job performance. These results support H3b.

\section{Discussion}

Our research contributes to making up for the shortage of current studies and confirming the influence of corporate philanthropy on organization commitment and job performance of employees. As predicted, corporate philanthropy has a positive effect on organization commitment and job performance. Raman has also demonstrated that the level of employees' organization commitment in the corporate that has donated to local charities is much higher than that of the enterprises that do not [25]. Thus, the humanitarian and charitable organizational atmosphere that enterprise philanthropy fabricates provides a nurturing environment that catalyzes spiritual experience for the employees, integrates the personal goals and the organization goal, and motivates employees to return better job performance to the organization. Besides, we also assess the intermediation of workplace spirituality between the enterprise philanthropy and employees' attitude and behavior. The research discovers that workplace spirituality partly mediates the relationships among the enterprise philanthropy, organization commitment and job performance. Organization commitment includes affective, continuous and normative commitment, so organization commitment is not only affected by emotions, but also affected by norms. Similarly, job performance includes two dimensions: contextual performance and task performance. Contextual performance, which is a spontaneous behavior, is mainly affected by emotions. Task performance, which is the regulated behavior and performance related to specific task, is often restraint by regulations and harmonious atmosphere in the organization. However, corporate philanthropy creates a virtuous atmosphere, which guides and restrains the employees' behaviors; meanwhile, the perception of the altruism will motivate employees to work harder. Workplace spirituality mainly provides an emotional experience to the employees, which includes the intrinsic value of work and organizational cohesion. And this kind of experience can improve the emotional state of the employees. Therefore, workplace spirituality plays a partly mediating role in the relationship between corporate philanthropy and job performance. So, the results proved the view of Ke, Sun and Qiu [12] partly, and other mediating variable exits probably.

\section{Practical Implications}

The practical implications of this study are as follows. Firstly, corporate should lay emphasis on the strategic value of philanthropy and engage in philanthropy activities to promote employees' workplace spirituality, organization commitment and job performance. Secondly, corporate is suggested to increase the job autonomy and challenge through work design, to make employees aware of the value and significance of the work and enhance the workplace spirituality of the employees. Finally, corporation ought to create a caring atmosphere for employees and strengthen their affirmations to the organization in the ways of committing human resource management practices or family-friendly human resource management practices, etc. Thirdly, corporate should con- 
firm employees' affirmation to the organizational value, thereby improving their workplace spirituality by means of organizational culture construction.

\section{Limitations and Directions for Future Research}

The limitations of this study are as follows: Firstly, the distributions of samples aren't wide enough. We mainly investigated the corporates in Beijing, which makes the research more prone to regionality. In the future study, the study could investigate corporates and employees from other regions to enhance the representativeness. Secondly, the study will carry out more longitudinal studies and multi-level variables research. Our research now mainly bases on the cross-sectional data, the internal validity of the study will be improved efficiently if we can carry out a longitudinal follow-up study. Lastly, the future research could introduce moderators including spiritual leadership, commitment human resource management and so on to enrich the theory. And further explorations on the mediators are also valuable, for example, from the perspective of organizational trust.

\section{Acknowledgements}

This paper is supported by National Natural Science Foundation of China (NSFC) "A research on the mechanism of corporate philanthropy's influences on the employees' attitudes and behaviors based on the workplace spirituality" (No. 71102020).

\section{References}

[1] Bateman, T. and Strasser, S.A. (1984) Longitudinal Analysis of the Antecedents of Organizational Commitment. Academy of Management Journal, 21, 95-112. http://dx.doi.org/10.2307/255959

[2] Meyer, J.P. and Allen, N.J. (1990) The Measurement and Antecedents of Affective, Continuance and Normative Commitment to the Organization. Journal of Occupational Psychology, 63, 1-18.

[3] Chen, X. and Duan, X. (2003) Organizational Commitment Review. Science of Science and Management of S. \& T., 7, 23-26.

[4] Rotundo, M. and Sackett, P.R. (2002) The Relative Importance of Task, Citizenship, and Counterproductive Performance to Global Aspects of Job Performance: A Policy-Capturing Approach. Journal of Applied Psychology, 87, 6680. http://dx.doi.org/10.1037/0021-9010.87.1.66

[5] Porter, M. and Kramer, M. (2002) The Competitive Advantage of Corporate Philanthropy. Harvard Business Review, 80, 56-69.

[6] Ke, J., Wu, D. and Fan, L. (2014) Research Advances in the Measurements, Causes and Effects of Corporate Philanthropic Behavior. China Human Resource Development, 305, 31-37.

[7] Gardberg, N.A. and Fombrun, C.J. (2006) Corporate Citizenship: Creating Intangible Assets Across Institutional Environment. Academy of Management Review, 31, 329-346. http://dx.doi.org/10.5465/AMR.2006.20208684

[8] Wang, H.L. and Qian, C.L. (2011) Corporate Philanthropy and Corporate Financial Performance: The Roles of Stakeholder Response and Political Access. Academy of Management Journal, 54, 1159-1181. http://dx.doi.org/10.5465/amj.2009.0548

[9] Wu, S. (2014) Study on Utility Philanthropy of Corporations. Cross-Cultural Communication, 10, 197-200.

[10] Ke, J., Sun, J. and Wu, D. (2015) Corporate Philanthropic Behavior Scale and Its Impact on Employees' workplace spirituality. Research on Economic and management, 35,100-108.

[11] Balakrishnan, R., Sprinkle, G.B. (2011) Contracting Benefits of Corporate Giving: An Experimental Investigation. The Accounting Review, 86, 1887-1907. http://dx.doi.org/10.2308/accr-10127

[12] Ke, J., Sun, J. and Qiu, X. (2014) Cross-Case Study on the Effects of Corporate Philanthropy on Employees' Work Attitudes and Behaviors. Journal of Management Case Study, 12, 436-448.

[13] Ashmos, D.P. and Duchon, D. (2000) Spirituality at Work: A Conceptualization and Measure. Journal of Management Inquiry, 9, 134-145. http://dx.doi.org/10.1177/105649260092008

[14] Milliman, J., Czaplewski, A.J. and Ferguson, J. (2003) Workplace Spirituality and Employee Work Attitudes: An Exploratory Empirical Assessment. Journal of Organizational Change Management, 16, 426-447. http://dx.doi.org/10.1108/09534810310484172

[15] Riasudeen, S. and Prabavathy, R. (2011) Relationship of Workplace Spirituality and Work Attitude in Manufacturing Organization. Global Management Review, 5, 29-37. 
[16] Rego, A. and Cunha, M.P. (2008) Workplace Spirituality and Organizational Commitment: An Empirical Study. Journal of Organizational Change Management, 21, 53-75. http://dx.doi.org/10.1108/09534810810847039

[17] Rastgar, A.A., Zarei, A., Davoudi, S.M .M. and Fartash, K. (2012) The Link between Workplace Spirituality, Organizational Citizenship Behavior and Job Performance in Iran. Arth Prabhand: A Journal of Economics and Management, 6, 51-67.

[18] Liu, Z. (2006) The Study on the Relationship between Employee Perceptions of Corporate Reputation and Employee Affective Commitment. Zhejiang University, Hangzhou.

[19] Cropanzano, R. and Mitchell, M.S. (2005) Social Exchange Theory, an Interdisciplinary Review. Journal of Management, 31, 874-900. http://dx.doi.org/10.1177/0149206305279602

[20] Morad, R.D., Mehrdad, G.C. and Roghayeh, B. (2012) Relationship between Job Satisfaction and Employee Job Performance in Guilan Public Sector. Journal of Basic and Applied Scientific Research, 2, 1735-1741.

[21] Muhammad, R., Islamabad, P., Dil, J.K. and Fawad, S. (2011) Relationship of Job Involvement with Employee Performance: Moderating Role of Attitude. European Journal of Business and Management, 8, 77-85.

[22] Ke, J., Qiu, X. and Ding, Q. (2014) The Influence of Spiritual Leadership on Organizational Citizenship Behavior and Job Performance of Subordinates-Workplace Spirituality as Mediator. Proceedings of the 2014 International Conference on Public Administration (ICPA 10th), Chengdu, 24-26 October 2014, 175-182.

[23] Tajfel, H. (1978) Differentiation Between Social Groups: Studies in the Social Psychology of Inter Group Relations. Academic Press, Waltham.

[24] Williams, L.J. and Anderson, S.E. (1991) Job Satisfaction and Organizational Commitments as Predictors of Organizational Citizenship and In-Role Behaviors. Journal of Management, 17, 601-617. http://dx.doi.org/10.1177/014920639101700305

[25] Rman, P. and Zboja, J.J. (2006) The Effects of Employee Attitudes on Workplace Charitable Donations. Journal of Nonprofit \& Public Sector Marketing, 10, 41-60. http://dx.doi.org/10.1300/J054v16n01_03 